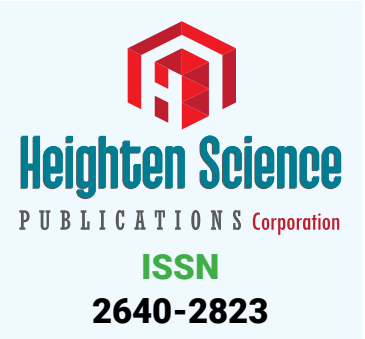

*Address for Correspondence: Dr. Melda Comert Ozkan, Inonu University, Malatya, Turkey, Tel: 903223904610 ; E-mail: meldacomert@hotmail.com

Submitted: 19 November 2016

Approved: 06 January 2017

Published: 09 January 2017

Copyright: @ 2017 Ozkan et al. This is an open access article distributed under the Creative Commons Attribution License, which permits unrestricted use, distribution, and reproduction in any medium, provided the original work is properly cited

Check for updates
Review Article

\section{Primary Cutaneous Lymphomas and Interferon Treatment}

\author{
Ajda ERSOY GUNES ${ }^{1}$, Melda COMERT OZKAN ${ }^{2 *}$, Fahri SAHIN ${ }^{3}$, \\ Guray SAYDAM ${ }^{3}$ \\ 'Department of Hematology, Sivas Numune Training Hospital, Sivas, Turkey. \\ ${ }^{2}$ Department of Hematology, Inonu University School of Medicine, Malatya, Turkey \\ ${ }^{3}$ Department of Hematology, Ege University School of Medicine, İzmir, Turkey
}

\section{ABSTRACT}

Primary cutaneous lymphomas (PCLs) are the second most common group of extranodal non-Hodgkin lymphomas (NHL) with an estimated annual incidence of 1/100.000. Interferons (IFNs) are used in mono or combination therapy for cutaneous lymphomas especially for cutaneous T-cell lymphomas (CTCL) for years. IFN- $a$ is the most widely-used type for cutaneous lymphomas. IFN- $a$ has been shown to be a highly active agent in CTCL with response rates ranging from $40 \%$ to $80 \%$. In this review, the current information about PCLs and IFNs treatment is summarized.

\section{INTRODUCTION}

Primary cutaneous lymphomas (PCLs) are defined that present in the skin with no evidence of extracutaneous disease at the time of diagnosis. After the gastrointestinal lymphomas, PCLs are the second most common group of extranodal non-Hodgkin lymphomas (NHLs) with an estimated annual incidence of 1/100.000 [1]. Classification is based on lymphocyte type: B-lymphocytes (B-cell) or T-lymphocytes (T-cell). PCL classification was developed by consensus of World Health Organization and European Organization for Research and Treatment of Cancer [2,3].

The most common PCL type is mycosis fungoides (MF) that is a type of CTCLs, representing $50 \%$ of all cases. Cutaneous B cell lymphomas represent 15 to $25 \%$ of PCLs. Treatment of PCLs is skin-directed in early disease stages, and systemic approach in advanced stages. Skin-directed therapies include topical corticosteroids, topical chemotherapy (mechlorethemine, nitrogen mustard, carmustine), local radiation, topical retinoids, phototherapy, topical imiquimod and total skin electron beam therapy. Systemic treatment options may be immunomodulatory, such as treatment with INF- $\alpha$ injection or biologic response modifiers such as bexarotene, HDACinhibitors, extracorporeal photopheresis, denileukin diftitox and chemotherapies such as methotrexate, etoposide, bortezomib, etc.

\section{Classification of cutaneous lymphomas}

PCLs have different clinical behavior and prognosis from nodal or systemic malignant lymphomas involving the skin secondarily. PCL classification was developed by consensus of World Health Organization and European Organization for Research and Treatment of Cancer [1] (Table 1). 


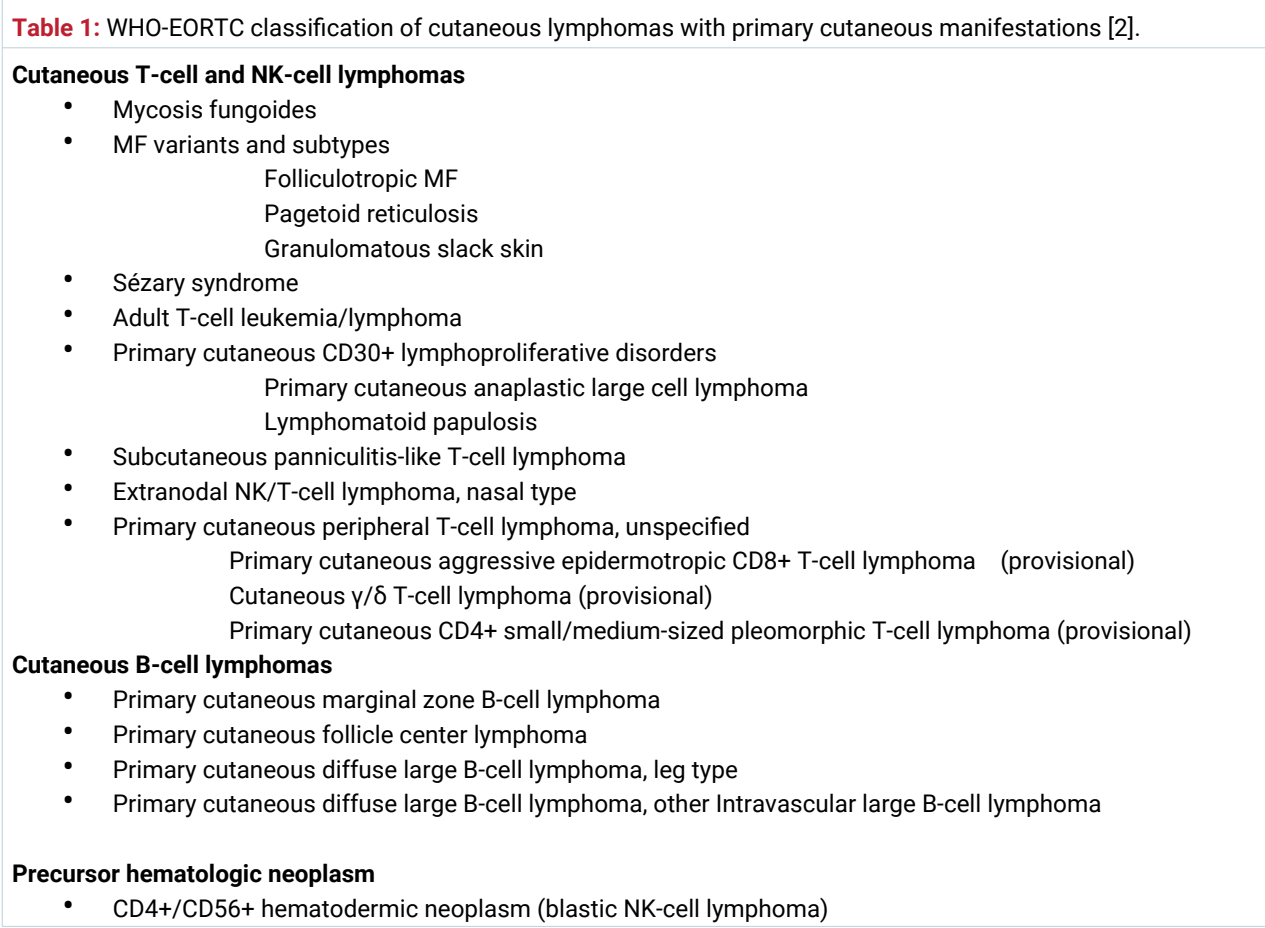

\section{Mycosis fungoides}

Mycosis fungoides (MF) is the most common form of PCLs. MF represents approximately $50 \%$ of PCLs, with an incidence estimated at 0.36 cases for every 100,000 individuals/year [2,4]. MF's incidence has risen over the last three decades [5]. Median age at diagnosis is 50-70 years, although pediatric and young adult cases occur [6,7]. MF is more frequent in males. MF represents less than $1 \%$ of the total number of NHLs and usually has an indolent course and good prognosis when identified in early stages.

The etiopathogenesis of MF is unclear but infectious agents [8], genetic and enviromental factors have been associated with the accumulation of T-lymphocytes in the skin, typically of the CD4 helper T-cell phenotype. Especially in cutaneous T-cell lymphoma (CTCL) patients serologic evidence of HTLV was determined. The major histologic findings of MF in skin biopsies are presence of an infiltrative lymphocytic accumulation in the superficial dermis, with cytologic atypia (dysplastic cerebriform $\mathrm{T}$ cells with pleomorphic, hyperchromatic, and convoluted nuclei) and individual lymphocytes migrating among epidermal keratinocytes, defines the so-called epidermotropism that is characteristic of MF. Although the epidermal clusters of lymphocytes around Langerhans cells defined as Pautrier microabcesses characteristic for MF, are not detected on all stages. In the early stages of MF, the T cell infiltrate include both malignant $\mathrm{CD} 4+$ and reactive $\mathrm{CD} 8+\mathrm{T}$ cells. In the later stages, malignant $\mathrm{CD} 4+$ cells increase and nonmalignant CD8+ cells decrease [9]. T-cells immunophenotyping is usually $\mathrm{CD} 3+, \mathrm{CD} 4+, \mathrm{CD} 45 \mathrm{RO}+, \mathrm{CD} 8-$, and generally lack normal $\mathrm{T}$ cell markers, such as CD7 and CD26. Other phenotypes associated with typical MF are CD8+, CD56+ and double negative, CD4- and CD8-. Expression of activation (HLA-DR, CD25, CD30, CD38) and proliferation antigens (CD71, ki-67) can be found in MF, particularly in the later stages.

MF presents with patch, plaque and tumor stages. Patches are frequently large $>5$ $\mathrm{cm})$, pruritic, erythematous and fine scaling leisons. They often vary in size, shape and color. Hypopigmention or hyperpigmention, epidermal atrophy, and telangiectasia may be determined. These lesions may remain stable for years, go into remission or indolently progress to plaque stage. Plaques are demarcated, at least $1 \mathrm{~mm}$ elevated lesions with erythema. In the early patch/plaque stages, diagnosis can be difficult and 
MF can be misdiagnosed as chronic eczema, psoriasis, parapsoriasis, sclero-atrophic lichen, chronic lichenoid pityriasis, pityriasis alba, atopic dermatitis etc., but suspicious lesions that are resistant to treatment should be considered MF. A tumor is defined as a dome-shaped solid skin lesion with elevation at least $5 \mathrm{~mm}$ above the skin surface, almost all of tumor leisons arise from previously existing patchs and plaques. In early stages MF often runs an indolent course.

Therapeutic strategies are primarily based on disease stage. Guidelines propose skin-directed therapies for the management of early stages of MF (IA, IB and IIB) $[10,11]$. Patients with only patches and/or plaques covering $<10 \%$ (stage IA) or $\geq 10 \%$ (stage IB) of the skin surface should be treated with skin-directed therapies and in patients developing one or a few tumours (stage IIB) additional local radiotherapy suffices [1].

Most widely used skin-directed therapy in early MF is topical corticosteroids. Other options are carmustine (BCNU), mechlorethamine, topical bexarotene, nitrogen mustard, local radiotherapy, surgical excision, and topical imiquimod. In widespread and late stage MF most effective treatment option is systemic treatment combined with local options (Phototherapy; narrow-band UV-B, psoralen-UV-A, or topical medications). Systemic treatment options are oral bexarotene, INFs or metotrexate. One of the skin-directed therapy option is photodynamic therapy (PDT) that consists of the application of a topical photosensitizer, procursor of protoporphyrin IX, which is taken up by the target cells, and illumination with an appropriate light source to cause the destruction of those cells [12].

\section{Sézary syndrome}

Sézary syndrome (SS) corresponds to $3 \%$ of all cutaneous lymphomas, and it is characterized by a triad of manifestations: erythrodermia with pruritus, lympadenopathy and atypical circulating lymphocytes with cerebriform nuclei (referred to as Sézary or Lutzner cells). Sézary cells in the dermis and Pautrier's microabscesses are often present in skin biopsies, histologically. A predominance of CD4+ lymphocytes in both skin biopsy and an absolute Sézary cell count of least 1000 cells/ $\mu$ in peripheral blood support a diagnosis of Sézary syndrome. Cytogenetic studies that demonstrate aneuploidy and DNA probe analysis that shows gene rearrangement for the $\mathrm{T}$ cell receptor are the most sensitive, and specific methods for identifying the clonal nature of the SS.

When systemic disease was defined, systemic treatment is required. Skin-directed therapies like PUVA or potent topical steroids may be used as adjuvant therapy. Extracorporeal photopheresis (ECP), either alone or in combination with other treatment modalities, has been suggested as the treatment option in SS with overall response (OR) rates of $30 \%-80 \%$, or complete response (CR) rates of $14 \%-25 \%$ [13]. Prolonged treatment with a combination of low-dose chlorambucil and prednisone is often effective in controlling the disease, but is unlikely to give CR. Low-dose methotrexate, bexarotene, denileukin diftitox, low-dose alemtuzumab, liposomal doxorubicin and multi-agent chemotherapy have been recommended as second-line treatment of SS [1].

\section{Adult T cell leukemia/lymphoma}

Adult T-cell leukemia/lymphoma (ATLL) is a form of mature CD4-positive T-cell lymphoma caused by HTLV-1. ATLL account for approximately 8-9\% of all cutaneous lymphomas. Three major findings required for diagnosis: 1) appearance of morphologically abnormal typically CD4+ and CD25+ T lymphocytes, 2) seropositivity for anti-HTLV-1 antibody and 3) Southern blot confirmation for monoclonal integration of HTLV-1 provirus into tumor cells [14]. Serologically anti-HTLV-1 
positive patients have a 3-5\% risk of developing ATLL and that the latency period is approximately 10-30 years [14]. Skin involvement is reported variably in $43-72 \%$ of patients. There is a cutaneous type of ATLL with lesions that persist without the development of extracutaneous involvement $[16,17]$. The skin lesions of ATLL are often clinically non-specific, and include papules, nodules, plaques, tumors, ulcerative lesions and erythroderma. ATLL has divided four clinical categories: smoldering, chronic, acute (leukemic subtypes) and lymphoma. Prognosis is severe because of intrinsic chemoresistance and severe immuosuppression [18]. Smoldering type has the best prognosis, with a $62.8 \%$ 4-year survival, followed by the other three types which range from $5 \%$ to $26.9 \%$ 4-year survival [19]. Of note, cutaneous ATLL may in fact have a better prognosis than classical ATLL [20]. Combinations chemotherapies can increase the response rates especially in the lymphoma subtype. However, patients have a high rate of relapse. The best chemotherapy regimens for aggressive clinical forms (acute, lymphoma, and unfavorable chronic) are VCAP-AMP-VECP regimen (vincristine, cyclophosphamide, doxorubicin, prednisone-doxorubicin, ranimustine, and prednisone-vindesine, etoposide, carboplatin, prednisone), which obtained a complete response rate (CRR) of 40\%. CHOP (cyclophosphamide, doxorubicin, vincristine, prednisone) regimen cen be used with 25\% CRR. Hyper-CVAD (cyclophosphamide, vincristine, doxorubicin, and dexamethasone-methotrexate, cytarabine) is acceptable as an alternative regimen [21]. Combination of Zidovudine and IFN- $\alpha$ shown to be effective in the leukemic subtypes in a meta-analysis. Allogeneic stem cell transplantation can be a option with high rate of complications [18].

\section{Primary cutaneous anaplastic CD 30+ large cell lymphoma}

Primary cutaneous anaplastic CD 30+ large cell lymphoma (PC-ALCL) is classified as tumour with indolent behaviour and represents about $10 \%$ of all CTCLs [22] Atypical gross morphology may result in false clinical suggestion of squamous cell carcinoma [23]. There are two sub-types of this disease. First of these is primary cutaneous anaplastic large cell lymphoma (PC-ALCL) which is characterized by solitary nodules and plaques [24]. It is composed of large anaplastic, pleomorphic, or immunoblastic T cells typically expressing CD30, but not ALK-1, and runs an indolent course with frequent, though limited cutaneous recurrences [25]. Surgical excision and radiotherapy have a curative potential for solitary lesions. Remissions with cytotoxic chemotherapy, occurring rapidly even after low-dose methotrexate or etoposide, are disappointingly short (months) in refractory cases, although retreatment is often successful. Anecdotal responses to imiquimod, bexarotene, retinoids, interferon, and thalidomide have been reported [26,27]. Second sub-type is Lymphomatoid papulosis (LyP). Papulonodular lesions develop, ulcerate, and then spontaneously heal in 3-12 weeks [2]. Patients with CD30+ LPDs are reported to be at increased risk for other neoplasms such as MF, Hodgkin disease, and NHL [28]. LyP is associated specifically with MF in 7-39\% of cases. LyP is an incurable disease but prognosis is favorable because lesions can spontaneously heal. There are no treatments proven to significantly alter the course of disease or prevent development of additional lymphoprolferative disease processes. Only about $4 \%$ of patients with LyP progress to systemic lymphoma [29].

\section{Subcutaneous panniculitis-like T-cell lymphoma}

Subcutaneous panniculitis-like T-cell lymphoma (SPTCL) is a rare type of PTCLs that typically affects young adults. It is characterized by the lobular infiltration of subcutaneous tissue by pleomorphic cytotoxic T-cells and benign macrophages that mimic panniculitis [30]. Skin and subcutaneous inflammation is often referred to as cytophagic histiocytic panniculitis which may be related to the SPTCL. Some SPTCL cases was reported after rituximab treatment. Patients generally present with solitary or multiple nodules or deeply seated plaques, which mainly involve the legs, arms, and trunk. Fifteen percent to $37 \%$ of patients accompanied by hemophagocytic syndrome 
(HPS). Elevated serum IL-18, a proinflammatory cytokine, induces interferon- $\gamma$ (IFN- $\gamma$ ) production by T and NK cells in HPS accompanied SPTCL cases [31]. SPTCL has an good prognosis, particularly if not associated with HPS [32]. HPS can be rapidly progressive and fatal despite the agressive chemotherapy regimens. Anthracycline-based chemotherapy regimens are the most commonly used and most effective systemic treatment options, producing long-term complete remission in $30 \%$ of patients [33].

\section{Extranodal natural killer (NK)/T-cell lymphoma (ENKTL), nasal type}

Extranodal natural killer (NK)/T-cell lymphoma (ENKTL), nasal type, is a rare and heterogeneous histopathologic subtype of NHLs that rare in Western countries but is more frequent in East Asia or in Central and South America. ENKTL is characterized by vascular damage and destruction, prominent necrosis, and association with EpsteinBarr virus (EBV) [34]. Tumors are mostly localized at nasal area especially in the nasal cavity or nasopharynx. Tumor cells are usually NK cells (surface CD3-, cytoplasmic $\mathrm{CD} 3 \epsilon+$, and CD56+) in most cases but in rare cases can also be T cells [35]. The prognosis is poor, with 5-year survival rates ranging from $32 \%$ to $49.5 \%$ [36]. Some current studies indicated that combination chemotherapies (cyclophosphamide, vincristine, doxorubicin, prednisone (CHOP) or gemcitabine, oxaliplatin, L-asparaginase (GELOX)) followed by involved field radiation therapy can be an effective and feasible treatment strategy for patients with stage IE/IIE ENKTL of the nasal area $[37,38]$.

\section{Primary cutaneous peripheral T-cell lymphoma, unspecified}

Primary cutaneous peripheral T-cell lymphoma, unspecified/not otherwise specified (PTL NOS) represents a phenotypically and prognostically heterogenous group of CTCLs. In the WHO-EORTC classification as well as the WHO classification, three entities have been delineated as provisional rare subtypes of PTL based on their characteristic clinico-pathological, immunophenotypic and prognostic features and have been separated out from PTL, NOS: Primary cutaneous CD4-positive small/ medium T-cell lymphoma (CD4+ SMTL), primary cutaneous CD8-positive aggressive epidermotropic T-cell lymphoma (CD8+ AECTCL), and primary cutaneous gamma/ delta T-cell lymphoma (CGD-TCL) [39].

\section{Interferons}

Interferons (IFNs) which are made and secreted by cells of the immune system were first discovered in 1957 by Isaacs and Lindenmann. There are three types of INFs: Type I; consisting primarily of IFN- $\alpha$ and IFN- $\beta$ (formerly known as leukocyte interferon and fibroblast interferon), type II; consisting of IFN- $\gamma$ (formerly known as immune interferon) and type III; consisiting of IFN- $\lambda$ which was identified during the recent years and classified as a new group. Type I IFNs are produced by many cell types, type II IFN (IFN- $\gamma$ ) is produced by T lymphocytes and NK cells, promote cellular immune responses and type III IFN- $\lambda$ receptors are highly expressed on hepatocytes [40] (Table 2).

IFNs have been successfully used in the treatment of several forms of malignancies. The effects of IFNs on malignancies depend on antiproliferative and modulatory effects on the immune response, indirect (antiangiogenetic) antitumour effects or direct antitumour mechanisms (cytotoxicity, up-regulation of cell surface molecules on tumour cells).

IFNs are used in mono or combination therapy for cutaneous lymphomas, especially cutaneous $\mathrm{T}$ cell lymphomas. IFN $\alpha$ has been shown to be a highly active agent in CTCL with response rates ranging from $40 \%$ to $80 \%$ [41,42]. IFN- $\alpha$ is the most often used type which has two variants IFN $\alpha-2 a$ and IFN $\alpha-2 b$. IFN $\alpha-2 b$ differs from IFN $\alpha$-2a by a single amino acid that arginine is used instead of lysine. There are no apparent differences in clinical efficacy [43]. In recent years, both IFN $\alpha$ types have 
Table 2: Interferon types and abbreviations [42].

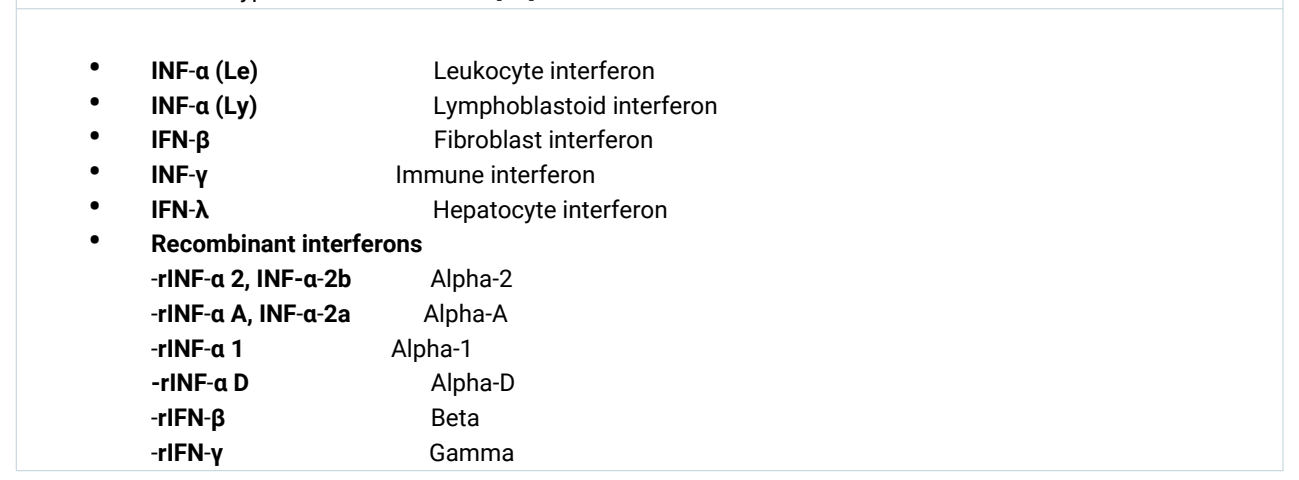

been developed by attachment of polyethylene glycol (pegylation), called pegylated interferon (PEG-IFN- $\alpha$ ). The mechanism of pegylation reduces its rate of absorption following subcutaneous injection, reduces renal and cellular clearance, and decreases the immunogenicity of the protein. Thus PEG-IFN- $\alpha$ has longer half-life and prolonged serum and tissue levels. PEG-IFN $\alpha$ 's efficacy has shown in severeal randomized studies but they are not yet approved for any antineoplastic therapy [44-47].

IFN- $\alpha$ is poorly absorbed from the gastrointestinal tract and is therefore administered parenterally. Subcutaneous injection is the usual route of administration. During the IFN $\alpha$ therapy many different side effects can occur with flu-like syndromes, gastrointestinal complaints, fatigue, pain, increased susceptibility to infections, thyroid dysfunction and psychiatric side effects. Taking IFN- $\alpha$ injections at night along with acetaminophene and diphenhydramine can minimize some of these side effects. Side effects frequently necessitate interruption and dose reduction. Toxicities also tend to be greater in older patients. Autoimmune disorders have been reported in patients who were treated with IFNs such as rheumatoid symptoms, a lupus-like disease, rheumatoid factor-positive monoarthritis, the antiphospholipid syndrome, diabetes mellitus, interstitial pneumonitis, autoimmune hemolytic anemia, autoimmune thrombocytopenia, psoriasis, leukocytoclastic vasculitis, thyroid disease, and autoimmune liver disease $[48,49]$.

IFN- $\alpha$ effectiveness and toxicity was first described by Bunn et al. in a clinical trial which involving 20 pretreated MF patients with advanced stage in 1984. High dose IFN- $\alpha 2 \mathrm{a}\left(50 \times 10^{6} \mathrm{U} / \mathrm{m}^{2}=50 \mathrm{MU} / \mathrm{m}^{2}\right.$ subcutaneously three times per week) was used in these patients [50]. In the late 1993, Ross et al. used continuous low-dose IFN monotherapy in 304 patients suffering from CTCL and demonstrated the overall response rate to IFN including complete, partial and minor responses in $70 \%$ and the best responses have been achieved in the early stages of the disease [51]. Mostow et al. reported that patients with disease refractory to PUVA alone can achieve a complete remission the combination of low-dose IFN- $\alpha$ with PUVA [52]. Rupoli et al. demonstrated CR in $19 / 25$ patients (76\%) and a PR in 5/25 patients (20\%) accounting for an overall response rate of $96 \%$ in 25 patients with early stage of mycosis fungoides ( stage I/ II disease) who treated with low dose of IFN $\alpha$-2b combined with PUVA. In this trial disease free survival projected to 48 months was $75 \%$ [53]. Subsequently in a multicentric prospective Phase II clinical study on 89 patients with early-stage IA to IIA MF treated for 14 months with low-dose IFN $\alpha-2 b$ (6-18 MU/wk) and PUVA, they have been reported that CR was achieved in $84 \%$ and an overall response rate in $98 \%$ of cases [54]. The treatment was well tolerated and treatment failure due to toxicity was not frequent in the patients.

Combination of IFN- $\alpha$ and retinoids has been reported active in CTCL patients by Knobles et al. [55]. In addition, according to a phase II trial of oral bexarotene combined with IFN- $\alpha$ for patients with cutaneous T-cell lymphoma to combine oral 
bexarotene treatment with IFN- $\alpha$ did not increase the response rate that would have been expected with bexarotene [56].

In the recent, pegylated IFN $\alpha-2 b$ plus psoralen PUVA versus standard interferon a-2a plus PUVA has been compared in 17 CTCL patients (stage IA-IV) by Hüsken et al. They have been reported that the median duration of PFS did not differ in either treatment group and 5-year relapse-free survival rates were higher in the PEGIFN $\alpha$-2b plus PUVA group. On the other hand the dose limiting side-effects, i.e. the favourable neuropsychiatric and constitutional toxicity were significantly less than the standard IFN $\alpha$-2a plus PUVA group [57]. Recent studies demonstrated that the use of IFN- $\gamma$ and IFN- $\beta$ in CTCL patients have no major advantage over IFN- $\alpha$ [58-60].

Primary cutaneous B-cell lymphomas (CBCLs) are much less common than primary cutaneous T-cell lymphomas (CTCLs) and include 3 main types: primary cutaneous marginal zone B-cell lymphoma (PCMZL), primary cutaneous follicle center lymphoma (PCFCL), and primary cutaneous diffuse large B-cell lymphoma, leg type (PCLBCL, LT). In the studies on limited number patients, intralesional treatment of PCFCL and PCMZL with IFN- $\alpha$ has been reported an effective choice for treatment [61-64].

\section{REFERENCES}

1. Willemze R, Dreyling M. Primary cutaneous lymphomas: ESMO Clinical Practice Guidelines for diagnosis, treatment and follow-up. Ann Oncol. 2010; 5: 177-180. Ref.: https://goo.gl/GOeMgn

2. Willemze R, Jaffe ES, Burg G, Cerroni L, Berti E, et al. WHO-EORTC classification for cutaneous lymphomas. Blood. 2005; 105: 3768-3785. Ref.: https://goo.gl/P3IMnA

3. Khader A, Manakkad SP, Shaan M, Sarita Sasidharan Pillai, Najeeba Riyaz, et al. A Clinicopathological Analysis of Primary Cutaneous Lymphomas: A 6-year Observational Study at a Tertiary Care Center of South India. Indian J Dermatol. 2016; 61: 608-617. Ref.: https://goo.gl/YI1QdG

4. Cerroni L. Past, present and future of cutaneous lymphomas. Semin Diagn Pathol. 2016; S0740 2570: 30091-30100. Ref.: https://goo.gl/8Qy076

5. Criscione VD, Weinstock MA. Incidence of cutaneous T-cell lymphoma in the United States, 19732002. Arch Dermatol. 2007; 143: 854-859. Ref.: https://goo.gl/gPa2op

6. Kim YH, Liu HL, Mraz-Gernhard S, Varghese A, Hoppe RT. Long-term outcome of 525 patients with mycosis fungoides and Sezary syndrome: clinical prognostic factors and risk for disease progression. Arch Dermatol. 2003; 139: 857-866. Ref.: https://goo.gl/2wkmlr

7. Wain EM, Orchard GE, Whittaker SJ, Spittle MF, Russell-Jones R. Outcome in 34 patients with juvenile-onset mycosis fungoides: a clinical, immunophenotypic, and molecular study. Cancer. 2003; 98: 2282-2290. Ref.: https://goo.gl/PKHTQY

8. Shohat M, Hodak E, Hannig H, Bodemer W, David M, et al. Evidence for the cofactor role of human T-cell lymphotropic virüs type 1 in mycosis fungoides and Sezary syndrome. $\mathrm{Br} \mathrm{J}$ Dermatol. 1999; 141: 44-49. Ref.: https://goo.gl/TlupYh

9. Chong BF, Wilson AJ, Gibson HM, Hafner MS, Luo Y, et al. Immune function abnormalities in peripheral blood mononuclear cell cytokine expression differentiates stages of cutaneous T-cell lymphoma/mycosis fungoides. Clin Cancer Res. 2008; 14: 646-653. Ref.: https://goo.gl/YFxt5v

10. Olsen E, Whittaker S, Kim Y, Duvic M, Prince HM, et al. Clinical end points and response criteria in mycosis fungoides and Sézary syndrome: a consensus statement of the International Society for Cutaneous Lymphoma, the United States Cutaneous Lymphoma Consortium, and the Cutaneous Lymphoma Task Force of the European Organisation for Research and Treatment of Cancer. J Clin Oncol 2011; 29: 2598-2607. Ref.: https://goo.gl/w1IKQA

11. Horwitz SM, Olsen EA, Duvic M, Porcu P, Kim YH. Review of the treatment of mycosis fungoides and Sézary syndrome: a stage based approach. J Natl Compr Canc Netw. 2008; 6: 436-442. Ref.: https://goo.gl/fW026Z

12. Guarino MF, Olasolo J. Photodynamic Therapy for Mycosis Fungoides. Actas Dermosifiliogr. 2013; 104: 393-399. Ref.: https://goo.gl/dAldUU

13. Wieselthier JS, Koh HK. Sézary syndrome: diagnosis, prognosis, and critical review of treatment options. J Am Acad Dermatol. 1990; 22: 381-401. Ref.: https://goo.gl/vWSrk3 
14. Sugaya M, Hamada T, Kawai K, Yonekura K, Ohtsuka M, et al. Guidelines for the management of cutaneous lymphomas (2011): A consensus statement by the Japanese Skin Cüancer Society Lymphoma Study Group. J Dermatol. 2013; 40: 2-14. Ref.: https://goo.gl/h09LQU

15. Yamada $\mathrm{Y}$, Tomonaga $\mathrm{M}$. The current status of therapy for adult T-cell leukaemia-lymphoma in Japan. Leuk Lymphoma. 2003; 44: 611-618. Ref.: https://goo.gl/Mt66w7

16. Takahashi K, Tanaka T, Fujita M, Horiguchi Y, Miyachi Y, et al. Cutaneous-type adult T-cell leukemia/ lymphoma. A unique clinical feature with monoclonal T-cell proliferation detected by Southern blot analysis. Arch Dermatol. 1988; 124: 399-404. Ref.: https://goo.gl/09v8nG

17. Camp B, Horwitz S, Pulitzer MP. Adult T-cell leukemia/lymphoma with follicular mucinosis: an unusual histopathological finding and a commentary. J Cutan Pathol. 2012; 39: 861-865. Ref.: https://goo.gl/3RQX66

18. Marçais A, Suarez F, Sibon D, Bazarbachi A, Hermine O. Clinical trials of adult T-cell leukaemia/ lymphoma treatment. Leuk Res Treatment. 2012. Ref.: https://goo.gl/Rfn1es

19. Sawada Y, Hino R, Hama K, Ohmori S, Fueki H, et al. Type of skin eruption is an independent prognostic indicator for adult T-cell leukemia/lymphoma. Blood. 2011; 117: 3961-3967. Ref.: https://goo.gl/RcWRWj

20. Nicot C. Current views in HTLV-I-associated adult T-cell leukemia/lymphoma. Am J Hematol. 2005; 78: 232-239. Ref.: https://goo.gl/QYsTcW

21. Oliveira PD, Farre L, Bittencourt AL. Adult T-cell leukemia/lymphoma. Rev Assoc Med Bras (1992). 2016; 62: 691-700. Ref.: https://goo.gl/PG4op5

22. Whittaker SJ, Mackie RM. Cutaneous lymphoma and lymphocytic infiltrates. In: Burns. T, Breathnach S, Cox N, Griffith C, editors. Rook's textbook of dermatology. Italy: Blackwell Science Ltd; 2004; 54.1-54.53. Ref.: https://goo.gl/gDAOeL

23. Biswas A, Gey van Pittius D, Stephens M, Smith AG. Reccurent primary cutaneous lymphoma with florid pseudoepitheliomatous hyperplasia masquerading as squamous cell carcinoma. Histopathology. 2008; 52: 755-758. Ref.: https://goo.gl/BIL8s1

24. Singh S, Gupta N, Tekta GR. Imprint cytology facilitating the diagnosis of primary cutaneous anaplastic large cell lymphoma of iliac fossa. J Cytol. 2012; 29: 267-269. Ref.: https://goo.gl/wkHmZU

25. Desai A, Telang GH, Olszewski AJ. Remission of primary cutaneous anaplastic large cell lymphoma after a brief course of brentuximab vedotin. Ann Hematol. 2013; 92: 567-568. Ref.: https://goo.gl/3s6FqN

26. Brice P, Cazals D, Mounier N, Verola O, Neidhart-Berard AM, et al. Primary cutaneous large-cell lymphoma: analysis of 49 patients included in the LNH87 prospective trial of polychemotherapy for high-grade lymphomas. Groupe d'Etude des Lymphomes de l'Adulte. Leukemia. 1998; 12: 213-219. Ref.: https://goo.gl/cDJl4L

27. Kempf W, Pfaltz K, Vermeer MH, Cozzio A, Ortiz-Romero PL, et al. EORTC, ISCL, and USCLC consensus recommendations for the treatment of primary cutaneous CD30-positive lymphoproliferative disorders: lymphomatoid papulosis and primary cutaneous anaplastic large-cell lymphoma. Blood. 2011; 118: 4024-4035. Ref.: https://goo.gl/e7SKZn

28. Magorien J, Hillman JD, Pinter-Brown LC, Said J, Chiu MW. Acral lymphomatoid papulosis associated with poikilodermatous mycosis fungoides. Dermatol Online J. 2013; 19: 1. Ref.: https://goo.gl/z5rlFM

29. Zackheim HS, Jones C, Leboit PE, Kashani-Sabet M, McCalmont TH, et al. Lymphomatoid papulosis associated with mycosis fungoides: a study of 21 patients including analyses for clonality. J Am Acad Dermatol. 2003; 49: 620-623. Ref.: https://goo.gl/zlqMbP

30. Dasanu CA, Gopal S, Davis LK, Atienza JA. Letter to the editor: Subcutaneous panniculitis-like T-cell lymphoma in a patient with history of B-cell lymphoma treated successfully with chemotherapy 15 years prior. Journal of Oncology Pharmacy Practice. 2013; 3: 1-3. Ref.: https://goo.gl/IdB5oc

31. Takada H, Ohga S, Mizuno Y, Suminoe A, Matsuzaki A, et al. Oversecretion of IL-18 in haemophagocytic lymphohistiocytosis: a novel marker of disease activity. $\mathrm{Br} \mathrm{J}$ Haematol. 1999; 106: 182-189. Ref.: https://goo.gl/7Rk3Sj

32. Willemze R, Jansen PM, Cerroni L, Berti E, Santucci M, et al. Subcutaneous panniculitis-like T-cell lymphoma: definition, classification, and prognostic factors: an EORTC Cutaneous Lymphoma Group Study of 83 cases. Blood. 2008; 111: 838-845. Ref.: https://goo.gl/ISngr0

33. Go RS, Wester SM. Immunophenotypic and molecular features, clinical outcomes, treatments, and prognostic factors associated with subcutaneous panniculitis-like T-cell lymphoma: a 
systematic analysis of 156 patients reported in the literature. Cancer. 2004; 101: 1404-1413. Ref.: https://goo.gl/t2Sy46

34. Li YJ, Li ZM, Xia Y, Huang JJ, Huang HQ, et al. Serum C-Reactive Protein (CRP) as a Simple and Independent Prognostic Factor in Extranodal Natural Killer/T-Cell Lymphoma, Nasal Type. PLoS One. 2013; 8: e64158. Ref.: https://goo.gl/oNQEPc

35. Suzuki R, Suzumiya J, Yamaguchi M, Nakamura S, Kameoka J, et al. Prognostic factors for mature natural killer (NK) cell neoplasms: aggressive NK cell leukemia and extranodal NK cell lymphoma, nasal type. Ann Oncol. 2010; 21: 1032-1040. Ref.: https://goo.gl/iFQWVh

36. Huang JJ, Jiang WQ, Lin TY, Huang Y, Xu RH, et al. Absolute lymphocyte count is a novel prognostic indicator in extranodal natural killer/T-cell lymphoma, nasal type. Ann Oncol. 2011; 22: 149-155. Ref.: https://goo.gl/Yq0ux8

37. Wang L, Xia ZJ, Huang HQ, Lu Y, Zhang YJ. Cyclophosphamide, doxorubicin, vincristine, and prednisone (CHOP) in the treatment of stage IE/IIE extranodal natural killer/T cell lymphoma, nasal type: 13-year follow-up in 135 patients. Int J Hematol. 2012; 96: 617-623. Ref.: https://goo.gl/clLN5q

38. Wang L, Wang Z, Chen X, Li Y, Wang K, et al. First-line combination of gemcitabine, oxaliplatin, and L-asparaginase (GELOX) followed by involved-field radiation therapy for patients with stage IE/IIE extranodal natural killer/T-cell lymphoma. Cancer. 2013; 119: 348-355. Ref.: https://goo.gl/tQsVFS

39. Kempf W, Rozati S, Kerl K, French LE, Dummer R. Cutaneous peripheral T-cell lymphomas, unspecified/NOS and rare subtypes: a heterogeneous group of challenging cutaneous lymphomas. G Ital Dermatol Venereol. 2012; 147: 553-562. Ref.: https://goo.gl/PexpGi

40. Kelly C, Klenerman P, Barnes E. Interferon lambdas: the next cytokine storm. Gut. 2011: 60; 12841293. Ref.: https://goo.gl/FW6H9N

41. Bunn PA Jr, Ihde DC, Foon KA. The role of recombinant interferon alfa-2a in the therapy of cutaneous T-cell lymphomas. Cancer. 1986; 57: 1689-1695. Ref.: https://goo.gl/se87HG

42. Olsen EA, Bunn PA. Interferon in the treatment of cutaneous T-cell lymphoma. Hematol Oncol Clin North Am. 1995; 9: 1089-1107. Ref.: https://goo.gl/Vp8QuD

43. Bunn PA Jr, Hoffman SJ, Norris D, Golitz LE, Aeling JL. Systemic therapy of cutaneous T-cell lymphomas (mycosis fungoides and the Sezary syndrome). Ann Intern Med. 1994; 121: 592-602. Ref.: https://goo.gl/U2pWkl

44. Quintas-Cardama A, Kantarjian H, Manshouri T, Luthra R, Estrov Z, et al. Pegylated interferon alfa-2a yields high rates of hematologic and molecular response in patients with advanced essential thrombocythemia and polycythemia vera. J Clin Oncol. 2009; 27: 5418-5424. Ref.: https://goo.gl/MzQeYo

45. Bottomley A, Coens C, Suciu S, Santinami M, Kruit W, et al. Adjuvant therapy with pegylated interferon alfa- $2 \mathrm{~b}$ versus observation in resected stage III melanoma: a phase III randomized controlled trial of health-related quality of life and symptoms by the European Organisation for Research and Treatment of Cancer Melanoma Group. J Clin Oncol. 2009; 27: 2916-2923. Ref.: https://goo.gl/kQoqiS

46. Feldman DR, Kondagunta GV, Schwartz L, Patil S, Ishill N, et al. Phase II trial of pegylated interferonalpha $2 b$ in patients with advanced renal cell carcinoma.Clin Genitourin Cancer. 2008; 6: 25-30. Ref.: https://goo.gl/6hQBVc

47. Bukowski R, Ernstoff MS, Gore ME, Nemunaitis JJ, Amato R, et al. Pegylated interferon alfa-2b treatment for patients with solid tumors: a phase I / II study. J Clin Oncol. 2002; 20: 3841-3849. Ref.: https://goo.gl/L9gP7C

48. Itoh $\mathrm{Y}$, Okanoue $\mathrm{T}$, Enjyo $\mathrm{F}$, Morimoto $\mathrm{M}$, Takeuchi $\mathrm{T}$, et al. Elevated interleukin- 6 and gammaglobulin during interferon therapy of hepatitis B. Am J Gastroenterol. 1992; 87: 1485-1487. Ref.: https://goo.gl/Vllfgy

49. Sacchi $S$, Kantarjian $H$, O'Brien $S$, Cohen PR, Pierce $S$, et al. Immune-mediated and unusual complications during interferon alfa therapy in chronic myelogenous leukemia. J Clin Oncol. 1995; 13: 2401-2407. Ref.: https://goo.gl/8qFG1E

50. Bunn PA Jr, Foon KA, Ihde DC, Longo DL, Eddy J, et al. Recombinant leukocyte A interferon: an active agent in advanced cutaneous T-cell lymphomas. Ann Intern Med. 1984; 101: 484-487. Ref.: https://goo.gl/xSpXeQ

51. Ross $C$, Tingsgaard $P$, Jorgensen $H$, Vejlsgaard $G L$. Interferon treatment of cutaneous $T$-cell lymphoma. Eur J Haematol. 1993; 51: 63-72. Ref.: https://goo.gl/VjYKUv 
52. Mostow EN, Neckel SL, Oberhelman L, Anderson TF, Cooper KD. Complete remissions in- psoralen and UV-A (PUVA)-refractory mycosis fungoides-type cutaneousT-cell lymphoma with combined interferon alfa and PUVA. Arch Dermatol. 1993; 129: 747-752. Ref.: https://goo.gl/rpkuD8

53. Rupoli S, Barulli S, Guiducci B, Offidani M, Mozzicafreddo G, et al. Low dose interferon-alpha2b combined with PUVA is an effective treatment of early stage mycosis fungoides: results of a multicenter study. Cutaneous-T Cell Lymphoma Multicenter Study Group. Haematologica. 1999; 84: 809-813. Ref.: https://goo.gl/1n56s0

54. Rupoli S, Goteri G, Pulini S, Filosa A, Tassetti A, et al. Long-term experience with low-dose interferonalpha and PUVA in the management of early mycosis fungoides. Eur J Haematol. 2005; 75: 136145. Ref.: https://goo.gl/G8VbPN

55. Knobler RM, Trautinger F, Radaszkiewicz T, Kokoschka EM, Micksche M. Treatment of cutaneous $\mathrm{T}$ cell lymphoma with a combination of low-dose interferon alfa-2b and retinoids. J Am Acad Dermatol. 1991; 24: 247-252. Ref.: https://goo.gl/9fG9LS

56. Straus DJ, Duvic M, Kuzel T, Horwitz S, Demierre MF, et al. Results of a phase II trial of ora bexarotene (Targretin) combined with interferon alfa-2b (Intron-A for patients with cutaneous T-cell Iymphoma. Cancer. 2007; 109: 1799-1803. Ref.: https://goo.gl/8k77Zz

57. Hüsken $A C$, Tsianakas $A$, Hensen $P$, Nashan $D$, Loquai $C$, et al. Comparison of pegylated interferon $a-2 b$ plus psoralen PUVA versus standard interferon $a-2 a$ plus PUVA in patients with cutaneous T-cell lymphoma. J Eur Acad Dermatol Venereol. 2012; 26: 71-78. Ref.: https://goo.gl/iyuuyK

58. Zinzani PL, Mazza P, Gherlinzoni F. Beta interferon in the treatment of mycosis fungoides. Haematologica. 1988; 73: 547-548. Ref.: https://goo.gl/itFFrc

59. Kaplan EH, Rosen ST, Norris DB, Roenigk HH Jr, Saks SR, et al. Phase II study of recombinant human interferon gamma for treatment of cutaneous T-cell lymphoma. J Natl Cancer Inst. 1990; 82: 208-212. Ref.: https://goo.gl/35Fjll

60. Jimbow K, Yamana K, Ishida O, Kawamura M, Ito Y, et al. Evaluation of rIFN-gamma in the treatment of lymphoma and melanoma of the skin by systemic and intralesional administration. Gan To Kagaku Ryoho. 1987; 14: 152-158. Ref.: https://goo.gl/Kaf9ab

61. Cozzio A, Kempf W, Schmid-Meyer R, Gilliet M, Michaelis S, et al. Intra-lesional low-dose interferon alpha 2a therapy for primary cutaneous marginal zone B-cell lymphoma. Leuk Lymphoma. 2006; 47: 865-869. Ref.: https://goo.gl/m9W0Pa

62. Kutting B, Bonsmann G, Metze D, Luger TA, Cerroni L. Borrelia burgdorferi-associated primary cutaneous $B$ cell lymphoma: complete clearing of skin lesions after antibiotic pulse therapy or intralesional injection of interferon alfa-2a. J Am Acad Dermatol. 1997; 36: 311-314. Ref.: https://goo.gl/iDdZNW

63. Parodi A, Micalizzi C, Rebora A. Intralesional natural interferon alpha in the treatment of Crosti's lymphoma (primary cutaneous B follicular centre-cell lymphoma): report of four cases. J Dermatol Treatment. 1996; 7: 105-107. Ref.: https://goo.gl/dBcl45

64. Zenone T, Catimel G, Barbet N, Clavel M. Complete remission of a primary cutaneous B cell lymphoma treated with intralesional recombinant interferon alpha-2a. Eur J Cancer. 1994; 30: 246247. Ref.: https://goo.gl/NgPT4z 